\title{
What the Posol'skii prikaz Really Knew: Intelligencers, Secret Agents and Their Reports
}

\author{
Daniel C. Waugh
}

The first part of this essay's title is a reference to two earlier publications about the knowledge level of the Muscovite Posol'skii prikaz, the ambassadorial office (diplomatic chancery). One is Knud Rasmussen's article about its information level in the sixteenth century, and the other Mikhail Alpatov's essay on the same subject focusing on the seventeenth century. ${ }^{1}$ Rasmussen and Alpatov reached rather different conclusions. Relying mainly on the instructions to Muscovite ambassadors, Rasmussen showed that, to a considerable degree, the Kremlin was out of touch with current events in Europe. Alpatov, on the other hand, citing the reports (stateinye spiski) written by Muscovite emissaries when they returned home, painted a much more positive picture of the way in which the Kremlin kept abreast of international affairs. Of course there is much else we might cite here to provide a full review of the relevant literature, but my task is a more modest one: to sketch out ideas and some examples from work in progress, in which I am examining the mechanisms for acquiring foreign news, the reliability of that news, and the degree to which its acquisition may or may not have played a role in the actual formation of policy.

A priori we must recognise that what may have been the case in the middle of the sixteenth century certainly was not equally true a century later. The frequency and reliability of Muscovite contacts with other countries had grown

1 Knud Rasmussen, 'On the Information Level of the Muscovite Posol'skij prikaz in the Sixteenth Century', Forschungen zur osteuropäischen Geschichte, 24 (1978), pp. 88-99; Mikhail A. Alpatov, 'Chto znal Posol'skii prikaz o Zapadnoi Evrope vo vtoroi polovine XviI v.?', in Istoriia i istoriki. Istoriografia vseobshchei istorii. Sbornik statei (Moscow: Nauka, 1966), pp. 89-129, reprinted in his Russkaia istoricheskaia mysl' i Zapadnaia Evropa XII-XVII vv. (Moscow: Nauka, 1973), pp. 323-363. The author gratefully acknowledges financial support which made possible part of this research from the Riksbankens jubileumsfond / The Bank of Sweden Tercentenary Foundation in conjunction with the project 'Cross-Cultural Exchange in Early Modern Europe', RFP12-0055:1, and from a grant from the National Endowment for the Humanities (RZ-1635-13): 'The Russian Court Theater in the late 17th Century and its Context in Trans-National Information Exchange'. Any views, findings, or conclusions expressed in this article do not necessarily represent those of the funding organisations. 
substantially, and there were means of obtaining news which had not existed earlier. The late Elena Kobzareva's kandidat dissertation focusing on Muscovite relations with England in the seventeenth century shows vividly how within a short space of two or three decades, the Kremlin went from blissful ignorance to some level of accurate information about English affairs. ${ }^{2}$ This, despite ingrained Russian views about politics which hindered any real understanding of what was going on during the Protectorate. Even if we were to look only at a decade or two in the second half of seventeenth century, we would discover a considerable unevenness in news acquisition and its use in Muscovy. A lot might depend on the subject of the news: for certain polities with which Muscovy dealt, geographic proximity and strategic importance might well dictate being better informed than might be the case for others (generally those more distant from Muscovy's borders). A particular negotiation might offer opportunities to obtain information that was not otherwise regularly available. In short, there are complexities here which require that we look beyond the texts of stateinye spiski and translations in the kuranty, the news compendia which became an important source of information for the Kremlin as the seventeenth century progressed. ${ }^{3}$ Yet to look beyond such sources then creates a host of additional challenges. Documentation may be scattered, a lot of what is essential not yet published. More generally, to say anything of substance about the making of Muscovite foreign policy over the course of something like a century requires detailed monographic study. With some exceptions cited below, too little that has been written on the subject has analysed closely

2 Elena I. Kobzareva, Izvestiia o sobytiiakh v Zapadnoi Evrope v dokumentakh Posol'skogo prikaza XVII veka (Unpublished diss., Moscow, 1988).

3 On the processes by which the stateinye spiski were created, see Aleksei A. Novosel'skii, 'Raznovidnosti krymskikh stateinykh spiskov XVII v. i priemy ikh sostavleniia', Problemy istochnikovedeniia, 9 (1961), pp. 182-194. Such reporting by returning ambassadors was normal procedure in other countries. See, for example, Phyllis S. Lachs, The Diplomatic Corps under Charles II and James II (New Brunswick, NJ: Rutgers University Press, 1965), pp. 42-45. For an overview of the history of the kuranty, see Daniel C. Waugh and Ingrid Maier, 'Muscovy and the European Information Revolution: Creating the Mechanisms for Obtaining Foreign News', in Simon Franklin and Katherine Bowers (eds.), Information and Empire: Mechanisms of Communication in Russia, 1600-1850 (Cambridge: Open Book Publishers, 2017), pp. 77-112. See also the monograph-length introduction by Ingrid Maier in the most recent volume of the ongoing series publishing the kuranty and their sources, Ingrid Maier (ed.), Vesti-kuranty 1656 g., 166o-1662 gg., 1664-167o gg. Ch. 2. Inostrannye originaly k russkim tekstam (Moscow: Iazyki slavianskikh kul'tur, 2008), and Stepan M. Shamin, Kuranty XVII stoletiia. Evropeiskaia pressa v Rossii i vozniknovenie russkoi periodicheskoi pechati (Moscow and St. Petersburg: Al'ians-Arkheo, 2011). 
the acquisition and reliability of diplomatic intelligence and correlated it with specific decision-making.

It is important to establish whether foreign policy decisions are based on accurate information and a clear understanding of international politics. Certainly there are many examples, even in our own day, of information overload, to illustrate how preconceived notions, wrong assumptions or misinformation led to bad decisions. ${ }^{4}$ Muscovy is no exception here, which does not mean that the Muscovite officials were in any way naïve about their sources. In fact, just the opposite seems to have been the case: they were very suspicious about the reliability of what they were told. The terms they used to describe information suggest as much: slukhi is commonly used to specify unverified rumour; 'nam podlinno vedomo' ('we know for certain') generally introduces information deemed to have come from a reliable source. The need to verify news was taken seriously, especially in the situation where there was no single institutionalised mechanism for acquiring it. Ultimately, I think, what was important was the degree of personal trust in the source of information. In this regard, Muscovy was no different from the rest of Europe. Trusted agents often had proven their worth by carrying out specific commissions that may have had little to do with the acquisition of news. ${ }^{5}$ Such agents tended to have their own networks of reliable contacts and had secure channels of communication. While it would be wrong to label all acquisition of news through agents as espionage, such clandestine activity was everywhere to be found. Despite its importance, it has been the subject of too little systematic investigation.

Of course, even the most trusted agents might in fact prove to have been unworthy of that trust. They might deliberately or unwittingly mislead in what they reported. Vera Chentsova's work on some of the Greek reports on the Balkans and the Ottoman Empire illustrates very well the potential for deliberate deception on the part of those who wished to obtain Muscovite support of one

4 The key figure in the making of Muscovite foreign policy in the 166os, Afanasii Lavrent'evich Ordin-Nashchokin, was one of the best informed men of his time; yet his insistence on pursuing policies that were at odds with political realities ultimately compromised his goals. See Boris N. Floria, Vneshnepoliticheskaia programma A.L. Ordina-Nashchokina i popytki ee osushchestvleniia (Moscow: INDRIK, 2013).

5 See Hans Cools, Marika Keblusek, and Badeloch Noldus (eds.), Your Humble Servant: Agents in Early Modern Europe (Hilversum: Uitgeverij Verloren, 2006). Stepan Shamin (e-mail 25 July 2017) has reminded me that, beyond my few examples in what follows, there is a great deal more to be said about Russian efforts to create a network of agents in Europe in the seventeenth century. 
kind or another. ${ }^{6}$ Often during a sensitive diplomatic negotiation, each side would share intelligence reports, hand over copies of letters from outside interested parties, and the like. A very interesting example of this was the Danish mission to Moscow led by Frederik von Gabel in $1676 .{ }^{7}$ Well before he arrived in Moscow, he was sending messages to the Kremlin - from Danzig, Vilna, and then Smolensk - trying to convince the Russians that the Poles, Swedes and Brandenburg, with French encouragement, were conspiring in an alliance ultimately directed against Muscovy. The point, of course, was to persuade the Russians to sign an alliance with Denmark directed against Sweden. Even though the Russian resident in Warsaw was reporting similar information, the tsar's government seems not to have been convinced. The Dane's mission failed. Sometimes information so provided was not false, but its transmission was deliberately delayed in the hope that an agreement or concessions might be obtained before the latest news destroyed any rationale for them.

There is a longstanding belief that Muscovite foreign policy was handicapped by the near absence of permanent representatives or agents abroad. However, we need to be careful in assessing the impact of having or lacking long-term residents in foreign capitals. ${ }^{8}$ A comparative perspective is useful here. The reports sent to London by British residents posted in northern Europe suggest that there was a considerable range in the substance and reliability of what they communicated. A number of factors explain this. The person of the resident was important: was it an individual of some social status,

6 Vera G. Chentsova, Ikona Iverskoi Bogomateri (Ocherki istorii otnoshenii grecheskoi tserkvi s Rossiei $v$ seredine XVII v. po dokumentam RGADA) (Moscow: INDRIK, 2010). Chentsova here and in other publications and Shamin (e-mail 25 July 2017) also emphasise how important the Greek Orthodox were in the Balkans as a source of reliable information about the Ottoman Empire.

7 Aleksandr N. Popov, Russkoe posol'stvo v Pol'she v 1673-1677 godakh. Neskol'ko let iz istorii otnoshenii drevnei Rossii k evropeiskim derzhavam (St. Petersburg: Tip. Morskogo kadetskogo korpusa, 1854), Chapter 12.

8 The locus classicus for any discussion of the rise and importance of permanent diplomatic representation is still Garrett Mattingly, Renaissance Diplomacy (Boston: Houghton Mifflin, 1971; 1st ed. 1954), but it was rare that any European power's representatives abroad could match the achievements in the level of knowledge and ability to report it regularly that was attained by the Venetian baili even as early as the late fifteenth century. For Habsburg diplomatic intelligence, see Charles Howard Carter, The Secret Diplomacy of the Habsburgs, 1598-1625 (New York and London: Columbia University Press, 1964), esp. Pts. 3-4. On the intelligence gathering and communications concerns of seventeenth-century English diplomatic personnel, see Lachs, The Diplomatic Corps, esp. pp. 30-46. 
education and foreign experience, well connected with the British foreign secretaries, or was it a relative non-entity? Perhaps more important was whether the home office kept the resident informed regularly and accurately about the news involving Britain. Thomas Thynne, the agent in Stockholm for many years, continually complained about his not being kept informed on a regular basis by his contact in Whitehall, the redoubtable spymaster Joseph Williamson. ${ }^{9}$ As Thynne explained, if he was going to be offered insider information through his contacts in Stockholm, he had to have something to offer in return, beyond what might be reported through the Haerlemse Courant, which was one of the main sources (and not, in his opinion, an unbiased one) of printed foreign news received in the Swedish capital. Hamburg, as a commercial and communications centre, was undoubtedly more important as a listening post for Britain. For a good many years, the British representative there was Sir Peter Wyche, who had once even headed a British embassy to Moscow in the 166 os. Wyche's reports suggest that he had an excellent network of contacts with all the other foreign residents in Hamburg, with diplomatic missions that passed through, and even with agents he hired in some of the other imperial cities. ${ }^{10}$ It was the norm for these British residents to send a report in practically every regular mail, which from Stockholm ideally was weekly, but from Hamburg could mean more often. Hamburg was the collecting point for reports coming from further east in the Baltic or from Poland.

The Muscovite government in fact had some experience regarding the value of having a long-term resident in another capital. Starting well back in the sixteenth century, there had been regular representation at the court of the Crimean Khan." The real limitation there was not so much the acquisition of intelligence, since well-placed bribes generally produced inside information from amongst the Tatar elite, and there were ample opportunities to quiz merchants and others arriving from the Ottoman Empire. Rather, there was always

Thynne's letters are in National Archives (London), sP 95/6. State Papers Foreign, Sweden, 1665-1668. See esp. fols. 143-144v, Thynne to Williamson, 20 February 1666; fols. 145-146v, Thynne to Williamson, 27 February 1666. Williamson's intelligence network, one of the best in any state at the time, has been analysed by Peter Fraser, The Intelligence of the Secretaries of State \& Their Monopoly of Licensed News 1660-1688 (Cambridge: Cambridge University Press, 1956), esp. Chapters 3-5.

10 For Wyche's reports, National Archives (London), sP 82/16, State Papers Foreign, Hamburg and Hanse Towns, 1678-1686, beginning on fol. 100 with Wyche to Joseph Williamson, 17 December 1678. Of particular interest for his review of his sources and their reliability is fol. 218, Wyche to Secretary of State Sir Lionell Jenkins, 15 October 1680.

11 See Aleksei V. Vinogradov, Russko-krymskie otnosheniia 5o-e - vtoraia polovina $70-k h$ godov XVI veka (2 vols., Moscow: Institut rossiiskoi istorii RAN, 2007). 
the question of how rapidly the information might be transmitted to Moscow. This required sending of special couriers, whose travel at times was deliberately blocked by the Tatars. A careful examination of Muscovite relations with the Crimea and the Ottomans reveals the importance of the reports sent or brought back from the Crimea by the Muscovite representatives there. ${ }^{12}$

Certainly by the 1640 s, the Muscovite government must have understood the value of having a long-term resident at least in neighbouring European territories. For more than half a year in 1643-1644, a Rigan writing under the nom de plume of Justus Filimonatus was sending reports from Riga and Danzig, though it seems he was unable to persuade the Muscovite authorities to hire him on an extended basis. ${ }^{13}$ For several months in 1649 , a Russian embassy to Sweden sent back to Moscow translations of German newspapers received in Stockholm. ${ }^{14}$ The example of the Swedish residents in Moscow who, at least from the 165 os, were sending regular reports to their government, surely was not lost on the Kremlin, and in fact around 166o, the Muscovite government on at least two occasions tried (unsuccessfully) to arrange to be supplied on a regular basis with foreign news from abroad, by hiring correspondents if not by actually stationing its own representatives in another capital. The establishment of the Muscovite foreign post on a regular basis in 1665, connecting to Riga, ensured the regular delivery of newspapers and newsletters, which, however, were no substitute for having an agent on the ground who could ferret out confidential information. ${ }^{15}$

The first appointment of a Russian resident at a European court followed on the Truce of Andrusovo in 1667. It provided for an exchange of Russian and

12 In addition to the evidence in Vinogradov's focused study, this is apparent in the more general but dated treatment of Russo-Ottoman relations by Nikolai A. Smirnov, Rossiia $i$ Turtsiia v XVI-XVII vv. (2 vols., Moscow: Moskovskii universitet, 1946).

13 For his reports, see N.I. Tarabasova et al. (eds.), Vesti-kuranty 1642-1644 gg. (Moscow: Nauka, 1976), pp. 40-43, 54-55, 59-74, 76-8o, 83-84, 97-103, 109-113, 126, 131-138, 146-147, $167-172,178-183$.

14 See the discussion by Ingrid Maier, 'Newspaper Translations in Seventeenth-Century Muscovy. About the Sources, Topics and Periodicity of Kuranty "Made in Stockholm" (1649)', in Per Ambrosiani (ed.), Explorare necesse est. Hyllningsskrift till Barbro Nilsson (Stockholm: Almqvist \& Wiksell, 2002), pp. 181-190.

15 On the establishment and functioning of the Muscovite foreign post, see Daniel C. Waugh, 'Istoki sozdaniia mezhdunarodnoi pochtovoi sluzhby Moskovskogo gosudarstva v evropeiskom kontekste', Ocherki feodal'noi Rossii, vyp. 19 (2017), pp. 394-442. The classic and still valuable study by Ivan P. Kozlovskii, Pervye pochty i pervye pochtmeistery $v$ Moskovskom gosudarstve (2 vols., Warsaw: Tip. Varshavskogo uchebnogo okruga, 1913), publishes many of the relevant documents. 
Polish residents, even if some years elapsed before they were in place. The establishment of the Vilna foreign postal route (to supplement that already in place via Riga) was in the first instance to ensure regular and rapid communication between these residents and their superiors at home. The mission of the first Russian resident in Poland, the stol'nik Vasilii Mikhailovich Tiapkin, was examined in some detail a century and a half ago by Aleksandr Popov, who based his study mainly on Tiapkin's stateinyi spisok and on his extensive correspondence with the then head of the Posol'skii prikaz, Artamon Matveev, and his immediate successors. ${ }^{16}$ Popov tells us nothing about Tiapkin's qualifications for the job, but he surely must have known Polish and maybe Latin. He would later be sent as an envoy to the Crimea. Tiapkin's mission lasted from late 1673 until the middle of 1677 . Near the end of his mission he became disillusioned with his ability to obtain reliable news, isolated both by the Poles and by his Moscow superiors after the downfall of Matveev. A closer look at Tiapkin's residency suggests that he was in fact quite successful as an agent reporting regularly on internal Polish-Lithuanian affairs. This, despite deep suspicions harboured by each government (and leading echelons of society) regarding the other side, and their vested interest in spreading as much disinformation as truthful news.

Tiapkin's assignment was a challenging one, given the fact that within Poland-Lithuania, there were so many competing political factions and he arrived during the interregnum following the death of King Michał Wiśnowiecki. In the first instance, Tiapkin's source of information was the Lithuanian Chancellor Hetman Krzysztof Pac. Information channelled through the Lithuanian magnates would continue to be of central importance for subsequent Muscovite news coming out of its neighbour to the West. When Tiapkin presented his credentials, his demands as to how he was to be treated show that the Posol'skii prikaz understood what a resident diplomat should be authorised to do if he was to be a source of reliable information. Those demands, to all of which Pac agreed, included free access to the king and the Rada, unhindered access to any other foreign diplomats, and permission to send couriers back to Moscow and to obtain news sent to the Polish chancery of foreign affairs from other states. As Tiapkin put it, these were the same privileges held by the Polish resident then already in Moscow. We know that Pac in fact frequently sent one of his secretaries to Tiapkin with requests or information, and arranged meetings with him. Naturally, this Lithuanian connection had the potential to bias considerably the information Tiapkin might obtain, both with regard to the upcoming election of the king and once Jan Sobieski had been selected. There 
was ongoing suspicion of Sobieski's intentions on the part of both the Polish and Lithuanian magnates, who felt the new king was scheming to make the elective Polish monarchy into a hereditary and absolutist one. Tiapkin seems to have made a serious effort to confirm the accuracy of anything he was told and clearly was sceptical about a lot of it. He did not confine himself merely to reporting, but expressed his own opinions and gave advice to his superiors. Apart from the frequent conversations with the Lithuanian party, he would be approached by representatives of the Polish elite, on more than one occasion had private conversations with Sobieski, and of course picked up a great deal else from conversations with visiting diplomats. All of his informants, naturally, were trying in some way via Tiapkin to influence Muscovite foreign policy decisions. Whoever was talking with Tiapkin proclaimed how trustworthy they were and favourably inclined to Muscovite interests - which must have made him suspect that they were protesting too much. In some cases, where he was hearing conflicting reports, he bluntly confronted Pac, demanding to know the truth. Tiapkin's counterpart in Moscow, pan Swidierski, presumably was experiencing the same thing, but also seems (deliberately) to have given preference to rumours unfavourable to Russian interests.

It was important for the resident to stay close to the court, which in Sobieski's case might mean his campaign headquarters. Tiapkin had mixed success in obtaining permission to follow the monarch, who never stopped long in one place. Yet even when permitted, for Tiapkin to be able to travel as he deemed necessary and to be able to present himself in a manner befitting the representative of the tsar required money. Like so many of the English representatives abroad, he would complain about not being given sufficient funds and not having the personal financial resources to make up the difference. In one plea for better support, he told his bosses in Moscow that he needed a portrait of the tsar to hang in the room where he might receive visitors, since, after all, the other foreign representatives in Poland all had in their chambers portraits of their royal masters. In general Tiapkin was diligent in defending the honour of his government and had a clear idea of his own status: at one point he refused to interpret the words of a courier from Moscow for Prince Radziwill, insisting that he (Tiapkin) was an accredited diplomat and not a mere translator.

Since the acculturation of the Muscovite elite is relevant to any study of Muscovite foreign relations, it is worth noting that Tiapkin's son was with him in Poland and was permitted (by special dispensation from the king) to attend schools there, where he acquired a decent knowledge of Latin and Polish. At the point when the young Tiapkin was about to be sent off as a courier to Moscow, his father asked that he be granted a special farewell audience with the king, at which the young man delivered a prepared speech in those languages. 
Tiapkin wrote regularly to Moscow, at least weekly by the post, but sometimes using additional couriers. Judging from what Popov's monograph tells us, much of the correspondence seems to have been in cipher, though how secure it was is something we still might want to determine. Tiapkin reported on meetings of the national sejm as well as on meetings of the regional ones, provided verbatim accounts of his conversations with various officials and the king, and even recounted what purported to be private arguments between the king and his French queen regarding foreign policy matters. Often the news was labelled as rumour, although it is not always clear whether that was Tiapkin's designation or Popov's in writing about the resident's reports. Until more of the Muscovite diplomatic files have been published, it is impossible to establish the impact of Tiapkin's reports in Moscow. However, one may hypothesise that for the making of Muscovite military strategy, news arriving from Ukraine regarding the realities of Turkish, Tatar and Cossack affairs would have been more important than much of the information concerning the political squabbles in Poland.

Toward the end of his stay, when relations with Poland were strained because the Poles had signed a peace with the Turks and resented the fact that Muscovy had failed to send military support when it had been most needed, Tiapkin began to wonder whether it was possible to discern the truth in anything he was told. He was forbidden to travel to the court and required to stay in Warsaw, even if the main activity of government was being carried on elsewhere. Tiapkin blamed his inability to obtain good intelligence on the failure of Moscow to send Russian news which then could be traded and could be used to counter false reports being spread in Poland regarding Muscovite affairs. Earlier, when he had been receiving news regularly, he had even been able to impress Sobieski by telling him information from Ukraine which the king had not yet heard. In other words, here we have a situation analogous to that of Thomas Thynne, the English representative in Stockholm, whose effectiveness was compromised by his inability to obtain from London English news to trade for intelligence.

For the period following Tiapkin's residency, we now have an excellent monograph by Kirill Kochegarov covering the negotiations between Poland and Muscovy in the early 1680 s which resulted in the signing of the 'Permanent Peace' in $1686 .{ }^{17}$ Kochegarov has mined both published and archival sources and includes a range of detailed information on how the acquisition of news

17 Kirill A. Kochegarov, Rech' Pospolitaia i Rossiia v 1680-1686 godakh. Zakliuchenie dogovora o Vechnom mire (Moscow: INDRIK, 2008). My discussion on the following several pages is based on Kochegarov's book. 
fed into negotiations. Even though their existence has long been known, he is the first scholar to devote serious attention to reports the Kremlin was obtaining through the crucial years of the early 1680 s from a strategically placed agent. This example is worth closer examination here.

Beginning in 1680 and continuing right through to the signing of the Permanent Peace in 1686, as Kochegarov puts it, "a special agent of the Posol'skii prikaz in Smolensk, Nazarii Mikhailov syn Kraevskii, was sending the most valuable and detailed information to Moscow".18 Kraevskii was from an old Smolensk noble family. A convert to Orthodoxy, he entered Muscovite service in the 165os, was involved in the Andrusovo negotiations and in subsequent border adjudication. Interestingly, he never seems to have mastered Cyrillic; his intelligence reports to Moscow were in a kind of heavily Polonised Russian written in the Latin alphabet. The significance attached to them can be seen from the fact that his letters always were addressed directly to the head of the Posol'skii prikaz. Starting in 1682, his correspondent in Moscow was Vasilii Golitsyn, the influential favourite of the regent Tsarevna Sofiia Alekseevna. Kraevskii's reports were deemed so secret that the Smolensk military governors were given explicit instructions to forward them sealed to Moscow and not open them. On several occasions Kraevskii travelled to Moscow for direct consultations; in other instances, he crossed the border into Poland-Lithuania for clandestine meetings with his contacts there.

Some of what Kraevskii was forwarding to Moscow were the typical avvisi which circulated widely in Poland and to a fair degree replicated material coming in via the normal news channels that served as the sources for the kuranty translations. However, what made Kraevskii's reporting so significant was his close relationship with Augustin Konstantynowicz, an important administrative secretary (his title was pisar' grodskii mstislavskii), who for many years was a close confidant and functionary for the Trock commandant Michał Oginski. Konstantynowicz had earlier, in 1674, been sent to Moscow by the Lithuanian magnates who were trying to negotiate the candidacy of Tsarevich Fedor Alekseevich for the Polish throne. The Lithuanian connection, and Konstantynowicz's position as a privileged insider, then meant that a substantial amount of confidential information was being passed on to Moscow on a regular basis in the 1680s. Information transmitted through this channel moved in both directions. The Lithuanian side was also able to obtain confidential reports out of Moscow. While the specific content of individual dispatches might be known only to those privileged to be in the loop, the existence of this exchange was a badly kept secret. Both in Moscow and 
in Poland-Lithuania, suspicions about the Kraevskii-Konstantynowicz connection were widespread. At least for a time, the Kremlin suspected Kraevskii of being a double agent and decided therefore not to allow him to come to Moscow where he might ferret out information that the Posol'skii prikaz deemed too secret to share. When some of the documents Kraevskii was sending on to Moscow raised questions about his trustworthiness, he carefully deleted those comments before forwarding the rest. If indeed, as is possible, he was playing a double game, he certainly would not have wanted his employers in Moscow to know about such suspicions on the Lithuanian side.

The Kraevskii-Konstantynowicz connection did, however, facilitate the secret negotiations the Lithuanian magnates, Hetman Michał Pac and Oginski, were carrying on with Moscow outside the framework of formal PolishMuscovite diplomacy. For security reasons, they would insist that the originals of their letters not be sent on to Moscow, but only copies of them made by Kraevskii. As Kochegarov makes clear, the Lithuanian connection did mean that the 'news' being sent on to Moscow had a distinct and in some cases misleading bias. Given their ingrained hostility to Sobieski, whom they tarred with the accusation of his being too pro-French, Pac and Oginski were able at the very least to heighten suspicion in Moscow regarding Polish intentions. Pac and Oginski were quick to send on to Moscow information about Polish diplomatic missions to the Turks. Could the king's profession of his serious commitment to fighting the Turks really be trusted, or was he not rather planning to turn his forces against Muscovy? Since there no longer was a Russian resident in Warsaw in this period, the Posol'skii prikaz was limited in its ability to learn first-hand about the realities of Polish political intrigues and lacked the direct access Tiapkin had earlier had to the king.

Quite apart from the specific contribution of the Kraevskii-Konstantynowicz conduit, clearly other channels made it possible for each side to obtain important information which was not being readily communicated officially by either government. An example is the text of treaties. Moscow had pressed the Poles for the text of the Polish-Turkish treaty of Zhuravno signed in 1676, which the Poles refused to provide; therefore a copy was obtained by other means, even though the Posol'skii prikaz could not be certain of its authenticity. Similarly, the Poles wanted a copy of the Bahçe-Sarai treaty of 1681 ending at least temporarily the Muscovite war against the Turks and Tatars. A Russian embassy to Poland claimed it did not know the terms of the treaty, yet a copy of it had already been obtained in Poland. What we see then in a lot of the diplomatic sparring in this period is deliberate obstructionism with reference to information that was not being officially shared, even if in fact the contending parties already knew it in detail. Well before one important Polish embassy 
had set out for Moscow, the Posol'skii prikaz had obtained through Kraevskii a copy of the confidential instructions the ambassador had been given for the upcoming negotiations. At least on the Moscow end, in the absence of minutes of meetings in which decisions were taken, there can be no simple answer to questions regarding the relationship between the acquisition of a particular item of news (or dis-information) and foreign-policy decision-making. On the Polish side, the situation was somewhat different, in that positions taken in the deliberations of the sejm might well be reported, but then Sobieski's own intentions, where he certainly was engaging in his own diplomacy, are less easy to ascertain.

Apart from the intelligence communicated through diplomatic channels, the Kremlin had another significant source of political intelligence: reports (otpiski) sent to Moscow by its military governors (voevody) appointed to border posts. ${ }^{19}$ In his analysis of reports from Ukraine sent to the Razriadnyi prikaz (the office which supervised the voevody), Nikolai Ohloblin showed that information deemed of particular relevance to other jurisdictions - for example, the Posol'skii or Malorossiiskii prikazy (Office of Ukrainian Affairs) - would be passed on to them. These reports, and the mechanisms by which the intelligence in them was obtained, are clearly hugely important for any study of the information level of the court and the Posol'skii prikaz. A primary duty for voevody stationed near the borders was to keep a close eye on events in the neighbouring countries which might have a direct bearing on Muscovy's foreign relations. Ohloblin offered a tentative ranking of the reliability of the information obtained by the voevody from different sources. At the top of his list was what merchants related, followed in descending order of reliability by reports from former captives, reports by spies, and those from vykhodtsy, individuals who might arrive in suspicious or unclear circumstances. Interrogations of those who were not going beyond Kiev and presumably had an obligation to return whence they came were recorded by the Kievan officials and ultimately forwarded to Moscow. Interrogations of escaped captives or those hoping to proceed to Moscow or gain some favour in Muscovite service were recorded locally, but the individuals then sent on to be interrogated once again when they had arrived in the Russian capital. The second interrogations generally were more thorough and often revealed details not in the preliminary ones or even contradicted some of what had earlier been recorded. Here are two examples which will illustrate the importance of the voevodskie otpiski and the complexities of analyzing intelligence obtained at Muscovy's borders.

19 See the seminal article by Nikolai Ogloblin (Ohloblin), 'Voevodskie "vestovye otpiski" XVII v. kak material dlia istorii Malorossii', Kievskaia starina, 12 (1885), pp. 365-416. 
In the late 1660 s and early $1670 s$, a rebellion led by the Cossack Stepan Razin challenged the survival of the Muscovite state. While in its initial phases the disturbances on the lower Volga and into the Caspian Sea seemed little different from earlier incidents of Cossack piracy, the movement grew rapidly, and in 1670 the rebels were capturing important Russian towns and even seemed to be threatening to move on Moscow itself. This was not merely an internal Muscovite affair, as it affected relations with Persia, and the home territory of Razin's Don River Cossacks was in fact beyond Muscovy's southern border and in proximity to the territories of the Crimean Tatars and their Ottoman suzerains. As the rebellion spread, the urgency of obtaining information about it grew. An analysis of the published reports from the border commanders illustrates well the ways in which information was obtained and transmitted, much of it coming from merchants, one-time captives of the rebels, and agents sent into rebel-held territory. ${ }^{20}$ What was initially vague and conflicting rumour gave way to verifiable reporting, and that in turn provided an explicit justification for policy decisions. Moreover, the Posol'skii prikaz seems to have been charged with assembling a history of the rebellion from several years of reports, in order that it then could be used to counter wild rumours about the imminent collapse of Muscovy which were fodder for Western newspaper reports. The Kremlin had a particular sensibility to any Western reporting that seemed to impugn the dignity of the tsar or suggest weakness of the Muscovite state.

My second example is from the mid-168os and relates to intelligencegathering in Kiev, as recorded in the remarkable diary of the Scottish mercenary Patrick Gordon. ${ }^{21}$ Gordon arguably was the most accomplished of all the mercenaries to enter Muscovite service. He had played a key role in the heroic,

20 For the Razin rebellion, see E.A. Shvetsova, et al. (eds.), Krest'ianskaia voina pod predvoditel'stvom Stepana Razina. Sbornik dokumentov (4 vols., Moscow: Izdatel'stvo Akademii nauk sssR, 1954-1976). I have analysed a portion of these reports in Daniel C. Waugh, 'What Was News and How Was It Communicated in Pre-Modern Russia?', in Simon Franklin and Katherine Bowers (eds.), Information and Empire: Mechanisms of Communication in Russia, 16oo-1850 (Cambridge: Open Book Publishers, 2017), pp. 213-252 (esp. pp. 236-250). See also in that same volume, Ingrid Maier, 'How Was Western Europe Informed about Muscovy? The Razin Rebellion in Focus', pp. 113-151.

21 The following material is based on Daniel C. Waugh, 'The Best Connected Man in Muscovy? Patrick Gordon's Evidence Regarding Communications in Muscovy in the 17th Century',Journal of Irish and Scottish Studies, 7:2 (2014 [2015]), pp. 61-124 (here esp. pp. 114-121). The relevant volume of Gordon's diary is Dmitry Fedosov (ed.), Diary of General Patrick Gordon of Auchleuchries 1635-1699, Vol. IV: 1684-1689, (Aberdeen: University of Aberdeen Press, 2013). In the following section, references are made to the dates of the diary entries rather than the pages of the edition. 
if ultimately unsuccessful defence of Chyhyryn against the Turks in 1678 , following which he was posted to Kiev and given responsibility to organise and strengthen the fortifications of the city. In Kiev, Gordon moved easily in the circles of the Russian and Ukrainian elites, both secular and religious. Beyond Kiev he maintained a voluminous correspondence. His knowledge of military matters both on the domestic scene and internationally meant that his counsel was valued in decisions about policy. His detailed diary provides a good introduction to the acquisition and transmission of news at an important border post in 1684 and 1685 .

Since Muscovite borders in the south generally were not closed, there was a lot of coming and going, in the first instance by merchants, but also by clerics, messengers and others. In Gordon's phrasing, information arrived via "a Kyovish burgesse comeing from Nemerow", from "a Jew came from Byally Czerkiew", "a merchant come from Russe Lemberg" (that is, L'viv), "from people come out of Polland", from "men come from the Bania with salt" and so on. Clerics were an important source, their news sometimes obtained when Gordon visited a local monastery. A priest who apparently had seen the encounter provided one of the most detailed and perceptive reports about a key battle fought by the Poles against the Turks and Tatars.

Another important source of information arriving on a regular basis in Kiev was the voevoda's correspondence with other military officers and with Cossack leaders. Local troop deployments or instructions for the immediate strengthening of defensive works might be spurred by the receipt of such information, although normally any kind of major commitment of forces had to wait until the matter was cleared in Moscow, something that might well take a month or more. The exchanges with the Cossack leaders - in particular the Hetman of the Left Bank Cossacks, at this time Ivan Samoilovich - were very important. Samoilovich, of course, was also writing directly to Moscow, and clearly was concerned first and foremost with pushing Muscovite policies in ways that would benefit his own power. Even though Gordon was subordinate to the Kievan voevoda, the Scot also had his contacts in the Hetman's capital at Baturin. His correspondents there included both Samoilovich and his then chief lieutenant and eventual successor, Ivan Mazepa. Often it seems that the Cossack reports contained the most up-to-date information about the movements of the Crimean Tatars or efforts by the Poles to send spies or agitators across the borders to persuade Cossacks to go over to the Polish side.

The voevody were by no means simply passive recipients of information but were also proactive in acquiring it. On a number of occasions Gordon reported the results of military scouting expeditions outside of Muscovite-controlled territory. Of even greater interest is the fact that agents (spies) were sent to 
more distant locations, some of these individuals on the regular payroll of the Muscovite administration even if they had no clearly defined social or occupational status. One, Ivan Filonov Varilov, first mentioned in the 11 November 1684 entry, returned from another mission on 2 January 1685 . Whereas many of the reports obtained from visiting merchants about possible military manoeuvres seem not to have been so important as to require immediate forwarding to Moscow, Varilov's information about possible Polish negotiation with the Crimea and planning to attack Muscovy was deemed significant and was sent to the capital the following day 'by post'.

Another of these intelligence agents was Mikhail Suslov, "whom wee had sent to Polland \& Germany and went from hence the first of May last [1684]", returning to Kiev on 1 January 1685, a day before Varilov. On 4 January, Gordon summarised Suslov's rambling account of events in the Turkish wars far to the West, concluding with a note about rumours he heard on his way back through Poland about possible plans there to turn against Muscovy. One gets the sense that Suslov tended to exaggerate, an impression reinforced on the next day, when Gordon reported, "It was resolved to methodize \& epitomize Susluws newes \& send them to Mosko by post". Yet later in the year, after more of Suslov's intelligence reports had been confirmed from other sources, Gordon would write of him: "Susluf being a good bairne, as bringing good wares for their money, was dispatched againe for more".

Where such reports dealt mainly with the more distant wars against the Turks, the information probably would have been old by the time it reached Moscow. Arguably Varilov's detailed and fresh information from Poland, whether or not it was accurate, should have been of great interest in the Kremlin, as it might have really been news.

These examples and my earlier discussion should convey a sense of how widely we must cast our nets if we are to gain a full appreciation of the richness and value of the foreign news coming into Muscovy from so many different directions by the last decades of the seventeenth century. To compare Muscovy and the West, as we are wont to do, is at best a risky enterprise, for it is all too easy to reach simplistic conclusions about the progress of those slippery processes we term 'modernisation' or 'westernisation'. When I first began to work on this material several decades ago, I tended to side with Rasmussen's scepticism and question Alpatov's optimism about how well the Posol'skii prikaz was informed. Now I would want to take a much more nuanced approach and would venture that at least by the last decades of the seventeenth century, the Muscovite government had come a long way in connecting itself to the stateof-the-art means of obtaining foreign news that was to be found almost everywhere in Europe. Yet foreign news seems to have been of little consequence in Russia beyond narrow circles of the elite. 
In fact, much of what we know about the dissemination and consumption of news in other parts of Europe offers us little by way of meaningful comparison for any discussion of news more broadly in Muscovy. One obvious difference is that Muscovy had no published newspapers, and foreign news generally was treated as a state secret. Where for the rest of Europe, the rapid spread of print culture has been the focus for many studies of the dissemination of news, for Muscovy it is necessary to rely on still inadequately published manuscript material and, even more challenging, to consider how best to assess the role of oral communication. Possibly one result of such study may invite us to look afresh at the situation in the rest of Europe, reflected as it were, in the Russian mirror. ${ }^{22}$ The concerns of ordinary people, for whom news might mean many different things, may turn out to be similar wherever we cast our gaze.

22 I have in mind here the interesting comparative results obtained by the economic historian Alexander Gerschenkron and embodied in his book Europe in the Russian Mirror: Four Lectures in Economic History (Cambridge: Cambridge University Press, 1970). The Russian example led him to reassess conventional wisdom about 'economic backwardness' and the role of the state in overcoming it elsewhere in Europe. 